\title{
Status of the burbot (Lota lota L.) in the Lower Danube (Bulgaria) - a species threatened by climate change
}

\author{
Pencho G. Pandakov', Teodora M. Teofilova², Nikolay D. Kodzhabashev' \\ I Forestry University, Faculty of Forestry, Department of Hunting and Game Management, 10 Kliment \\ Ohridski Blvd., 1756 Sofia, Bulgaria 2 Institute of Biodiversity and Ecosystem Research (IBER), Bulgarian \\ Academy of Sciences, 1 Tsar Osvoboditel Blvd., 1000 Sofia, Bulgaria
}

Corresponding author: Pencho G. Pandakov (p.pandakov@gmail.com)

Academic editor: M.E. Bichuette | Received 31 October 2019 | Accepted 19 December 2019 | Published 10 February 2020

http://zoobank.org/C2C935EE-B9E4-4A59-AE46-8E267B8C9229

Citation: Pandakov PG, Teofilova TM, Kodzhabashev ND (2020) Status of the burbot (Lota lota L.) in the Lower Danube (Bulgaria) - a species threatened by climate change. ZooKeys 910: 143-161. https://doi.org/10.3897/ zookeys.910.47866

\begin{abstract}
The study provides data on the catch composition, length-weight relationship, age structure, gender structure, growth, maturation, fecundity, distribution and conservation status of the burbot Lota lota (Linnaeus, 1758) in Bulgaria. During six consecutive winters (2008-2014) a total of 395 burbot specimens were caught. The total length and the weight of the specimens ranged from 16 to $51 \mathrm{~cm}$ and 29.8 to $1057 \mathrm{~g}$, respectively. Seven age classes were represented (3- to 9-years-old), with 3-, 4-, and 5-years-old most abundant. The maximal life expectancy was estimated as 12 years. Male-female ratio was 1:1. Maturity happens at the age of four at the earliest, valid for both sexes. One-quarter of the fish, older than 5 years were determined as non-reproducing in the particular year. The absolute fecundity varied between 47462 and 810236 eggs for females ranging from 5 to 7 years old and from 25.7 to $41.5 \mathrm{~cm}$ in length. A dramatic decrease of burbot population was observed in the last two decades. Warming water temperatures of the Danube, together with fragmentation in its tributaries are considered as the major threats affecting the species. Therefore, the burbot in Bulgaria is classified as Endangered.
\end{abstract}

\section{Keywords}

Age structure, conservation status, fecundity, fragmentation, growth, length-weight relationship

Copyright Pencho G. Pandakov et al. This is an open access article distributed under the terms of the Creative Commons Attribution License (CC BY 4.0), which permits unrestricted use, distribution, and reproduction in any medium, provided the original author and source are credited. 


\section{Introduction}

The burbot is the only freshwater gadoid fish species (Berg 1949). It is thought this species' thermal preference is ecologically intermediate between thermal preferences of cold-water salmonids and more thermophilic cyprinids (Nikcevic et al. 1995). Burbot usually reduces and even arrests its feeding at summer temperatures, falling into a state of hibernation (Tyulpanov 1967; Hardewig et al. 2004). The species' behavior can be defined as crepuscular and nocturnal.

Although burbot is abundant throughout much of its natural range, there are many populations that are extirpated, endangered, or in serious decline (Stapanian et al. 2010). Burbot is thought to be an excellent indicator for habitat degradation and an early indicator of climate change (Stapanian et al. 2010; Edwards et al. 2011). In Europe, burbot have been extirpated from the United Kingdom, Belgium, and parts of Germany as result of the deterioration of habitats (Stapanian et al. 2010). In the Middle and Upper Danube basins, the species is considered vulnerable (Stapanian et al. 2010). The reported declines in the burbot populations in northern Europe is caused by pollution, acidification, eutrophication, fragmentation and invasive species (Pulliainen and Korhonen 1993; Kjellman 2003; Stapanian et al. 2010). Damming, river regulation, and pollution have caused the extirpation and decline of the species in Poland, Slovakia, Czech Republic, and Slovenia (Brylińska et al. 2002; Slavík and Bartoš 2002; Holcík 2003; Kruk 2007; Stapanian et al. 2010).

The species was widespread and very numerous in the Bulgarian section of the Danube during the first half of $20^{\text {th }}$ century (Kovachev 1923; Drensky 1951). Later, Pomakov (1985) reported a dramatic decline over 30 years and classified the species as Endangered (EN), mentioning that it had not been found since 1969. Burbot has since been down-listed to Vulnerable (VU) by Trichkova and Stefanov (2011) using data from the end of the last and the beginning of this century when the commercial burbot catch in the Danube had increased significantly. Karapetkova and Zhivkov (2010) have classified the species as occasional and threatened by extinction. The species has lost most of its localities in the major Danube tributaries in Bulgaria (Fig. 1).

Burbot also represents a target species for some commercial fisheries during winter, especially for the eastern Bulgarian section of the Danube. Listed as a game fish, size and harvest limits are imposed by the Fisheries and Aquaculture Act in Bulgaria. A few studies of populations from the Serbian part of the Middle Danube have been published during the last decades (Janković 1986, Nikcevic et al. 1995; Skorić et al. 2013; Višnjić-Jeftić et al. 2014; Smederevac-Lalić et al. 2015). Our study represents the first scientific survey of burbot populations in the Lower Danube and in particular in Bulgaria, since the species had been historically recorded by Kovachev (1923). We aim to provide biological data on the burbot population in the Lower Danube, to clarify the national Bulgarian conservation status of the species, and to provide data for the revision of its international conservation status. Currently, the species is listed as Least Concern (LC) in International Union for the Conservation of Nature (IUCN) Red List, and although the population trend and major threats are mentioned as unknown, there are a number of publications reporting severe negative impacts affecting the species worldwide (Stapanian et al. 2010). 


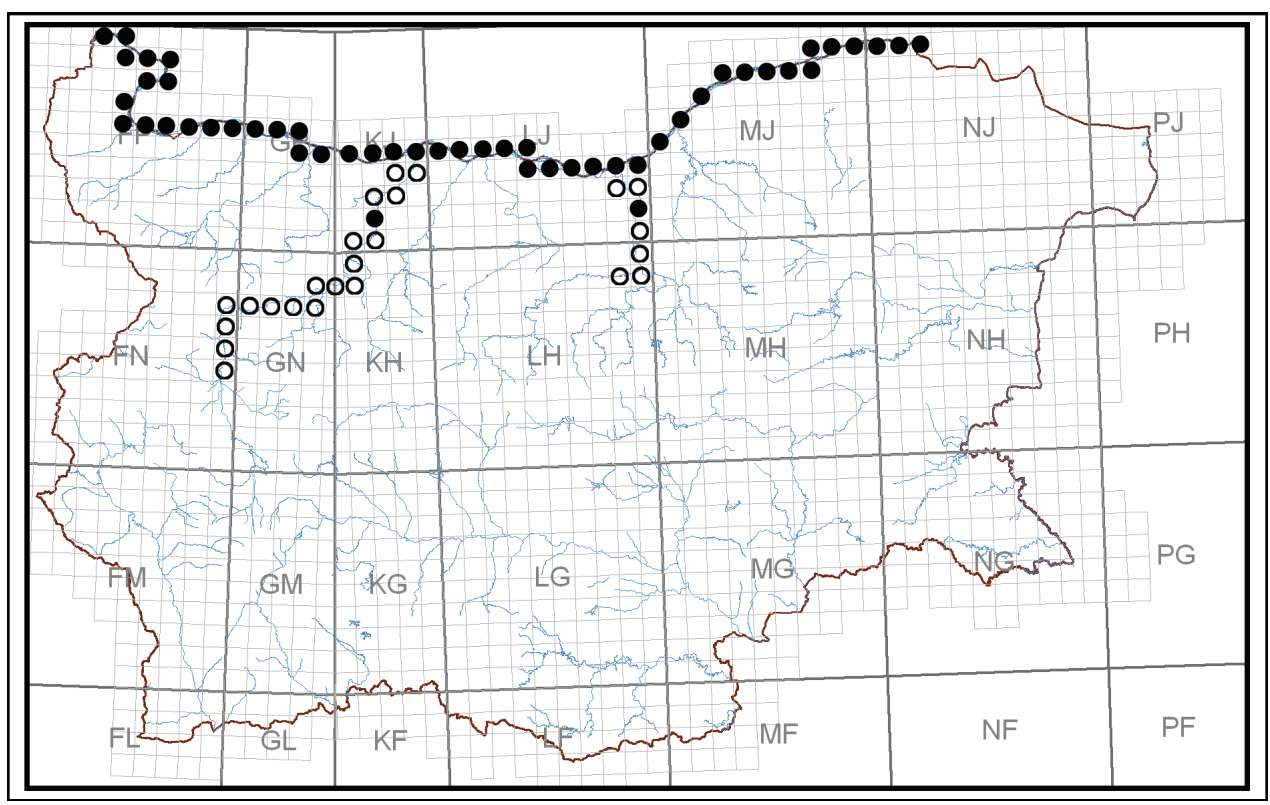

Figure I. Distribution of the burbot in Bulgaria presented via registration of the species in UTM $10 \times$ $10 \mathrm{~km}$ grid (o localities before 2002, • localities after 2002).

\section{Material and methods}

Field sampling was carried out from 2008 to 2014 in the Bulgarian section of the Danube River between the village of Malak Preslavets ( $\mathrm{km} 412$ on the river) and the town of Silistra $(\mathrm{km} \mathrm{375).} \mathrm{This} \mathrm{short} \mathrm{section} \mathrm{of} \mathrm{the} \mathrm{river} \mathrm{(only} 37 \mathrm{~km}$ ) was selected as a model case, because the commercial fishing efforts targeting the species are restricted here. More than $96 \%$ of all registered catches are coming from this stretch. In the rest of the Bulgarian section of the Danube, burbot catches are accidental. The provided fish for the study were caught by commercial fishermen, using hoop nets deployed at night or twilight in December and January along the shoreline in shallow waters with sandy-gravelly substrate and low to moderate flow velocity.

Collected fishes were immediately chilled in ice and transferred to the laboratory. All individuals were measured without any fixation and total length (TL) and wet weight $(\mathrm{W})$ were determined. The length-weight relation was expressed using the equation $\mathrm{W}=\mathrm{aTL}$ (Ricker 1975), where $a$ is the intercept and $b$ is the slope of the $\log$-transformed relation (Froese 2006). The parameters $a$ and $b$ were estimated by linear regression from the logarithmically transformed equation: $\log 10 \mathrm{~W}=\log 10 \mathrm{a}+$ blog10TL. Normal distribution of the data sets was checked, an F-test was performed to determine if the variances of the data sets were equal, and a t-test was applied to test the isometric pattern hypothesis $(b=3)$ and the significance in the difference between the mean length and weight of examined males and females by age classes. For all statistical analyses we rejected the null hypothesis if the $p$-value was less than 0.05 . 
We used vertebrae to estimate the age of the fishes, a method verified for the burbot by Guinn and Hallberg (1990). The individual vertebrae, taken from the zone between third and seventh column vertebrae, were freed from the connective tissue and cartilage of the vertebral column, without previous boiling or chemical immersion, using a scalpel and clamps, and then air dried. The age of the fish was rounded to the next integer number.

The gonads were removed from all individuals and the sex was determined. Specimens without any formed reproductive glands were perceived as juveniles. Those whose glands were thread-like were perceived as immature and a histological examination was used for their sex determination. Individuals with well-developed gonads, not containing sexual products together with the immature ones were grouped and classified as non-reproducing. The absolute fecundity of all 10 matured females in one of the collected catches (from 25.12.2008) was estimated. Their ovaries were weighed, and the eggs in the ovary were subsampled, counted using a stereomicroscope, weighed, and the total number calculated by direct proportion.

Growth rate of the population was described via the Bertalanffy Growth Function (Bertalanffy 1951) using Chapman's method (Chapman 1961) for the estimation of the growth parameters from observed length-age data: $\mathrm{Lt}=\mathrm{L} \infty\left(1-\exp \left(-\mathrm{k}\left(\mathrm{t}-\mathrm{t}_{0}\right)\right)\right)$, where $L t$ is the total length at age $t, L \infty$ is the length that the fish would reach at an infinitely high age or the asymptotic length at which growth is zero, and $\mathrm{k}$ is the curvature parameter; and $t_{0}$ is the theoretical age when the fish has zero length.

The statistical calculations as well as all figures and tables were performed using MICROSOFT OFFICE 2010. A distribution map was created using ADOBE PHOTOSHOP 7.0.

The conservation status of the species was classified according IUCN criteria (IUCN 2012b), applied at regional level (IUCN 2012a). Official data submitted by the Executive Agency of Fisheries and Aquaculture (EAFA) and Executive agency for exploration and maintenance of the Danube river (EAEMDR), supplemented by ours, were used for that purpose.

\section{Results}

\section{Catch composition by size and seasons}

A total of 395 burbot specimens were obtained. All of them were collected in first three seasons of the survey: 97 specimens in 2008/2009, seven specimens in 2009/2010, and 291 specimens in 2010/2011 winter seasons. In the winter of 2011/2012 all caught burbot were immediately released by the fishermen because of their small size (under the limit in the regulatory framework). During the winter 2012/2013 and 2013/2014 seasons the catches were extremely poor so we had no fish for examination.

Total length of the fish varied within the range of 160-510 mm (average: $263 \mathrm{~mm}$ ) and body weight from 29.8 to $1057 \mathrm{~g}$ (average: $160 \mathrm{~g}$ ). Length groups were established 


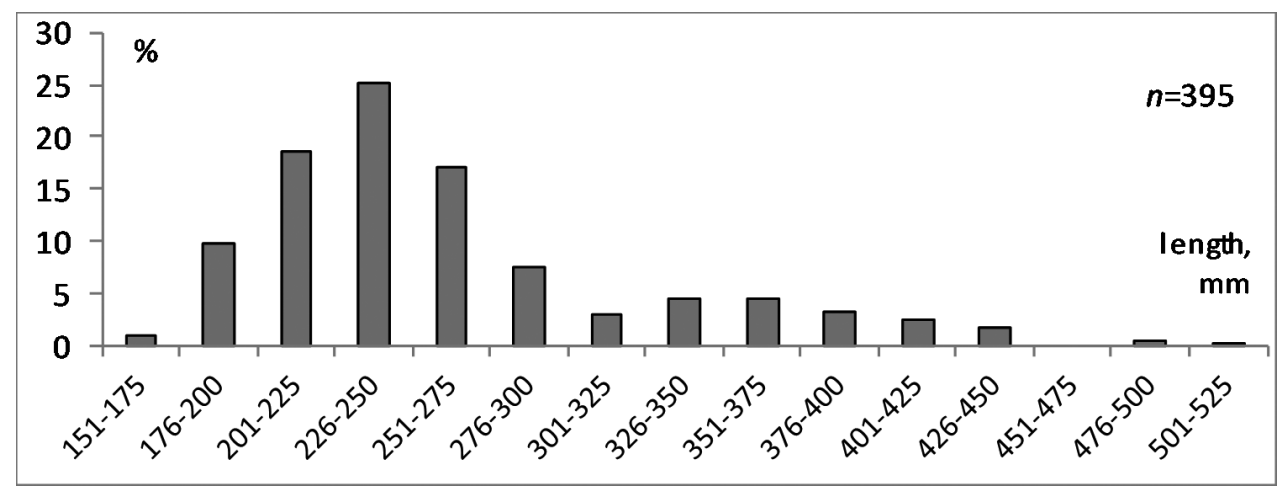

Figure 2. Distribution (in \%) of body length among studied burbots, as represented by 25-mm size classes.

at $25 \mathrm{~mm}$ and almost $80 \%$ of caught individuals referred to the first five size classes and only 20\% were distributed among the other eight classes (Fig. 2).

\section{Length-weight relationship}

The length-weight relation was calculated for all 395 individuals regardless of their gender (Fig. 3, left). The data were well described by the gradient curve expressed by the next equation: $\mathrm{TL}=60.872 \mathrm{~W}^{0.3019}$. There were not significant differences in mean length and weight among females and males for 3-, 4-, and 5-year-old fish ( $t$-test, $p$ > $0.05)$. Significant difference in mean length and weight among females and males $(p=$ 0.007 ) was found for 6-year-old females, which were characterized by a stronger decrease in length growth than the 6-year-old males. Different sexes in the other three age classes (7-, 8-, and 9-year-old fish) were not numerous enough for implementing such analysis. However, we described the length-weight relation for both sexes separately (Fig. 3, right), although significant difference among males and females was not found without taking in to account the age.

The parameters $a$ and $b$ were estimated by linear regression (Fig. 4) of the logarithmically transformed equation: $\log 10 \mathrm{~W}=3.3128 \log 10 \mathrm{TL}-5.9114$, with coefficient of determination $\left(\mathrm{R}^{2}\right)$ of 0.9527 . The value of the parameter $\mathrm{b}=3.3128$ was significantly different from 3 , showing positive allometric growth.

\section{Age}

All caught burbot exhibited an external incomplete year ring referring to the unfinished annual cycle. Most of the fish had the first inner hyaline circle on the base of the vertebra hardly visible (or sometimes absent), which corresponds to the very short (or sometimes absent) inactive period during the first summer. Age composition of 


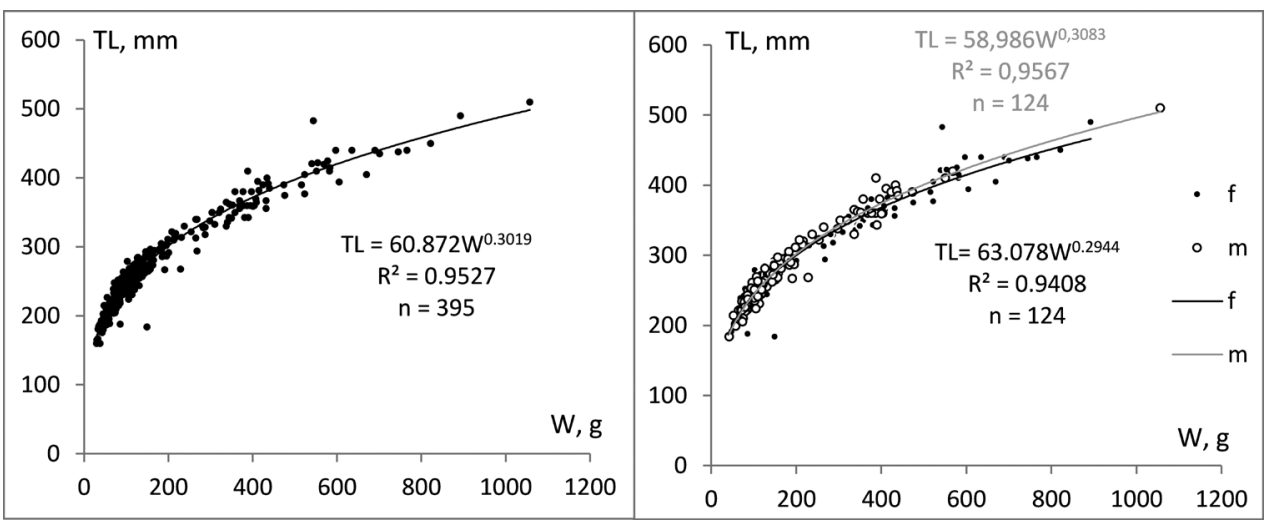

Figure 3. Length-weight relationship for all collected fish (left), and separate relationships for the both sexes (right); $\mathrm{TL}=$ total length and $\mathrm{W}=$ weight.

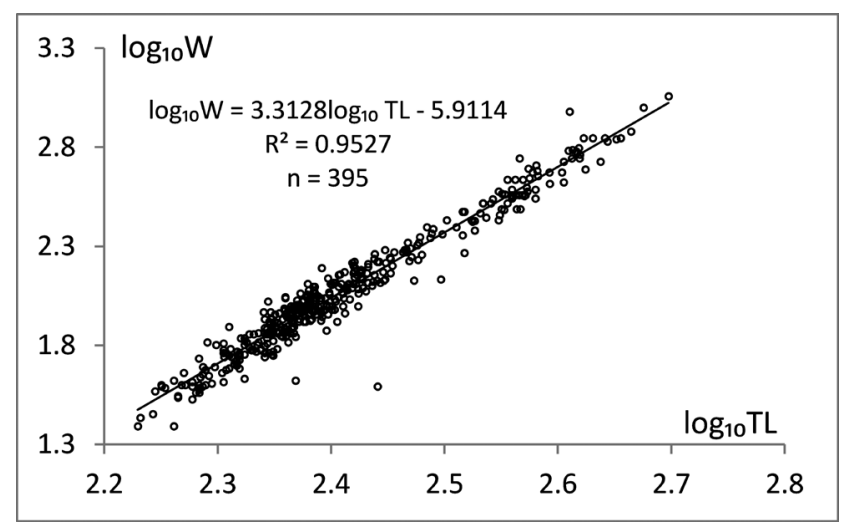

Figure 4. Length-weight relationship for the total catch expressed by linear equation.

the catches during the whole period, and for each season separately, is visualized in Figure 5. Most fish were 3, 4, and 5 years old. Seven different ages were represented in the catch, from 3- to 9-year-old fish.

The abundance of the age groups was the highest during the first winter season. The second season was characterized with only few obtained specimens, but all individuals were in a reproductive age distributed over only three age groups. During the winter of 2010/2011 (third season) the quantity of the caught fish was the highest but only composed of three age classes, and mainly by young individuals (3- and 4-year-olds).

\section{Gender and maturation}

With regards to sex composition, male-female ratio was 1:1 (124 males, 124 females). Males were slightly more numerous in the younger ages, while the females dominated in the elder ones. Our study showed that burbot in Bulgaria reach sexual maturity for the 


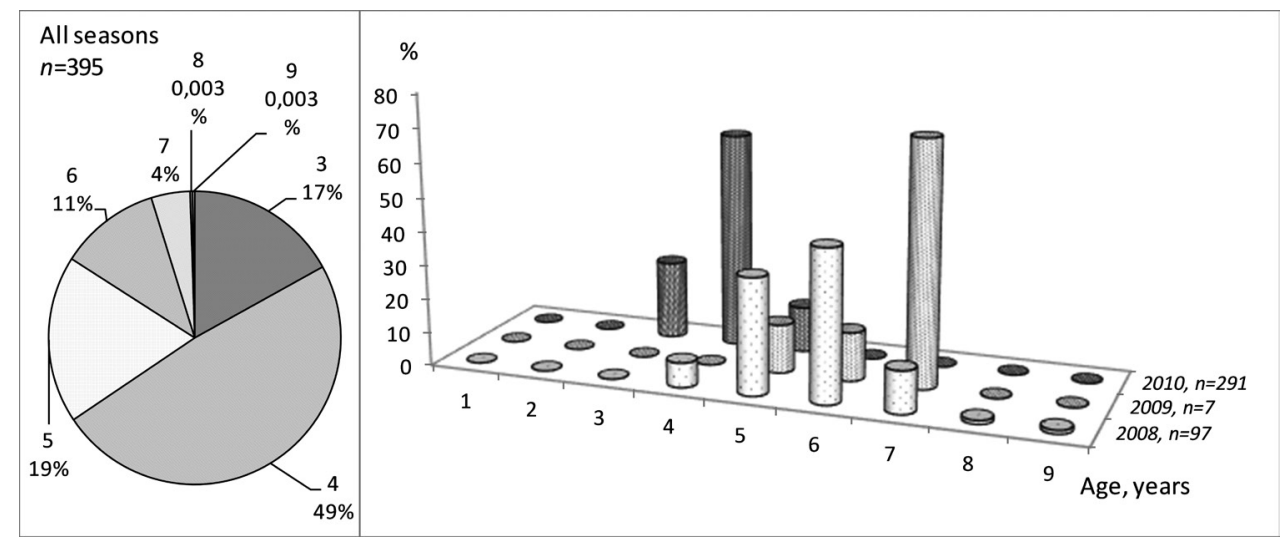

Figure 5. Age composition (in \%) of all collected burbot (left) and for each season separate (right). On the left diagram, the upper value is the age category and lower value is the percentage of this category in total number of fish.

Table I. Sex composition of the captured burbot.

\begin{tabular}{|c|c|c|c|}
\hline Age & Males & Females & Juveniles \\
\hline 3 & 7 & 7 & 53 \\
\hline 4 & 62 & 47 & 83 \\
\hline 5 & 29 & 33 & 11 \\
\hline 6 & 24 & 20 & 0 \\
\hline 7 & 1 & 16 & 0 \\
\hline 8 & 0 & 1 & 0 \\
\hline 9 & 1 & 0 & 0 \\
\hline Total & 124 & 124 & 147 \\
\hline
\end{tabular}

first time during their fourth year. The group of non-reproducing fish constituted 34\% of the fish older than four years and $25 \%$ of those older than five. In our catch, all 3-year-old burbot were juvenile or immature. At age of four, about two-thirds of the specimens are still immature in both sexes. Five-year-old and older specimens were generally mature (Table 1).

Although the fish were caught in the spawning season, there were females and males whose gonads were thin, small, and without any products. The gonads were unlike an empty sack, so it can be excluded that these fish had already released their eggs or semen before they were caught. However, most of the fish older than five years had well-developed gonads in the last stage of maturity.

\section{Fecundity}

The fecundity varied between 47462 and 810236 eggs for females ranging in age from 5 to 7 and from 257 to $415 \mathrm{~mm}$ in length. The fecundity of 5-year-olds was about 10 times less than 7-year-olds. There were positive correlations between the number of the eggs and the age of the females $(r=0.74)$, as well as between the number of eggs and the total length $(r=0.87)$ and the weight $(r=0.97)$ of female burbot. 


\section{Growth}

The values of the parameters $K, L \infty$ and $t_{0}$ in the von Bertalanffy growth equation were established as follows: $\mathrm{K}=0.085426, \mathrm{~L} \infty=1018.25, \mathrm{t}_{0}=-1.17262$. The growth rate can be described by the function: $\mathrm{Lt}=101.8250(1-\exp (-0.0854(\mathrm{t}+1.1726)))$ (Fig. 6). Based on the parameters of the established growth curve, young fish (up to 2 years) increase their size quickly, while later length growth gradually decreases (Table 1). According to the local fishermen, the largest captured specimens were always males with an approximate weight of $2.2 \mathrm{~kg}$. Using the polynomial equation established for males in Figure 3 (right), we calculated that these largest fish should be approximately $633 \mathrm{~mm}$ long, which equates to a maximum lifespan of the burbot in Bulgaria of about 12 years (Table 2).

\section{Distribution and conservation status}

There was a strong decline ( $>90 \%)$ in the registered catches by EAFA over the period from 2002 to 2018 (equivalent to 3-4 burbot generations) (Fig. 7). About 96\% of the

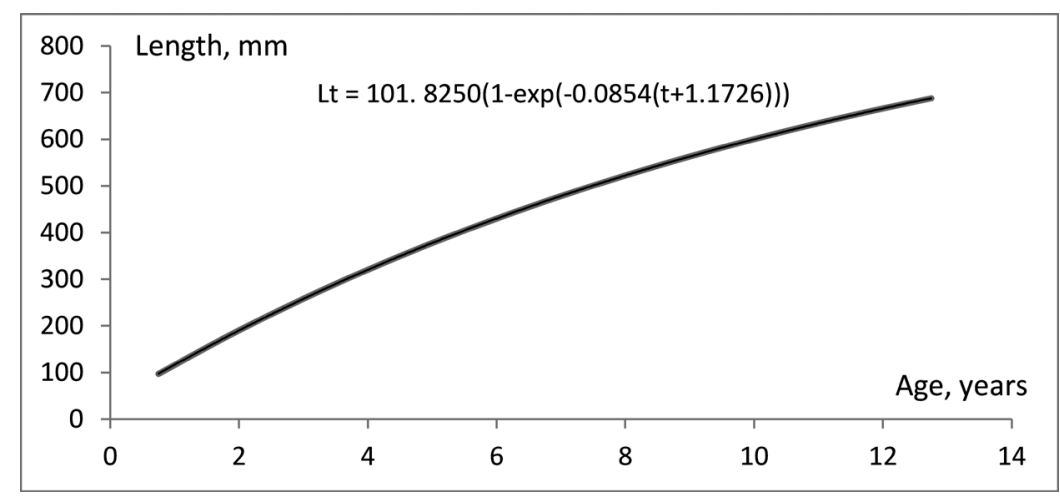

Figure 6. Growth curve of burbot in Bulgaria.

Table 2. Simulation of age-length relationship based on the von Bertalanffy equation.

\begin{tabular}{lcc}
\hline & Age & Total length, mm \\
\hline 1 & $1^{\text {st }}$ winter & 97 \\
2 & $2^{\text {nd }}$ winter & 172 \\
3 & $3^{\text {td }}$ winter & 242 \\
4 & $4^{\text {th }}$ winter & 305 \\
5 & $5^{\text {th }}$ winter & 364 \\
6 & $6^{\text {th }}$ winter & 417 \\
7 & $7^{\text {th }}$ winter & 466 \\
8 & $8^{\text {th }}$ winter & 512 \\
9 & $9^{\text {th }}$ winter & 553 \\
10 & $10^{\text {th }}$ winter & 591 \\
11 & $11^{\text {th }}$ winter & 626 \\
12 & $12^{\text {th }}$ winter & 658 \\
\hline
\end{tabular}


commercial catch comes from the eastern river section between Tutrakan and Silistra (Fig. 8) where the fishing effort targeting at this species is concentrated. The negative trend was shown clearly via the moving average trend line (Period $=2)$, which smooth out the yearly fluctuations. Therefore, the conservation status of the burbot in Bulgaria was classified as Critically Endangered (CR A2cd) according to IUCN criteria (IUCN $2012 \mathrm{~b})$. The category was down-listed in Endangered $\left(\mathrm{EN}^{\circ}\right)$, after correction for regional level of assessment (IUCN 2012a) due to rescue effect of Romanian and Serbian

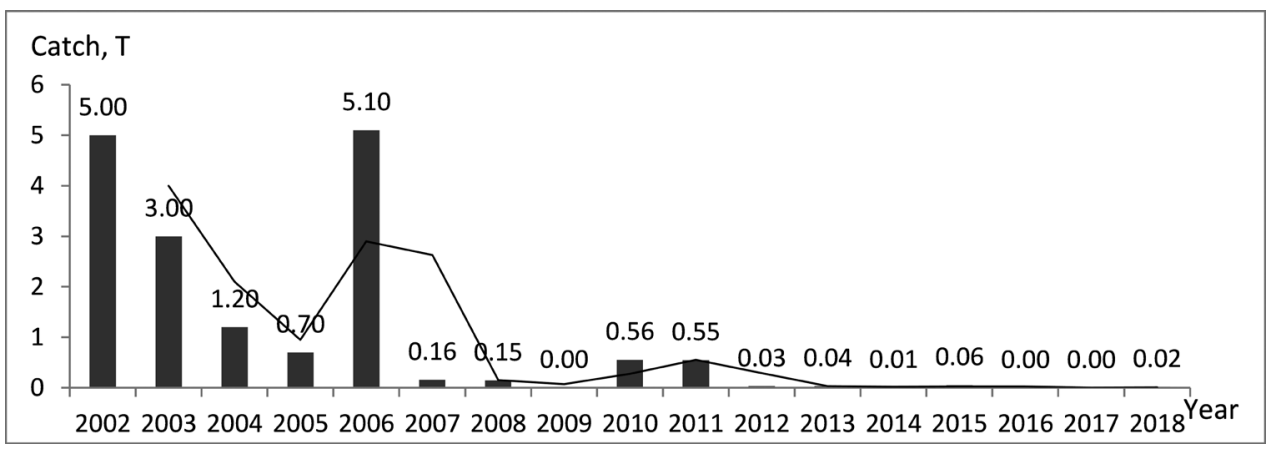

Figure 7. Commercial catch of burbot in Bulgaria, represented by calendar years (data source: The Executive Agency of Fisheries and Aquaculture (EAFA)).

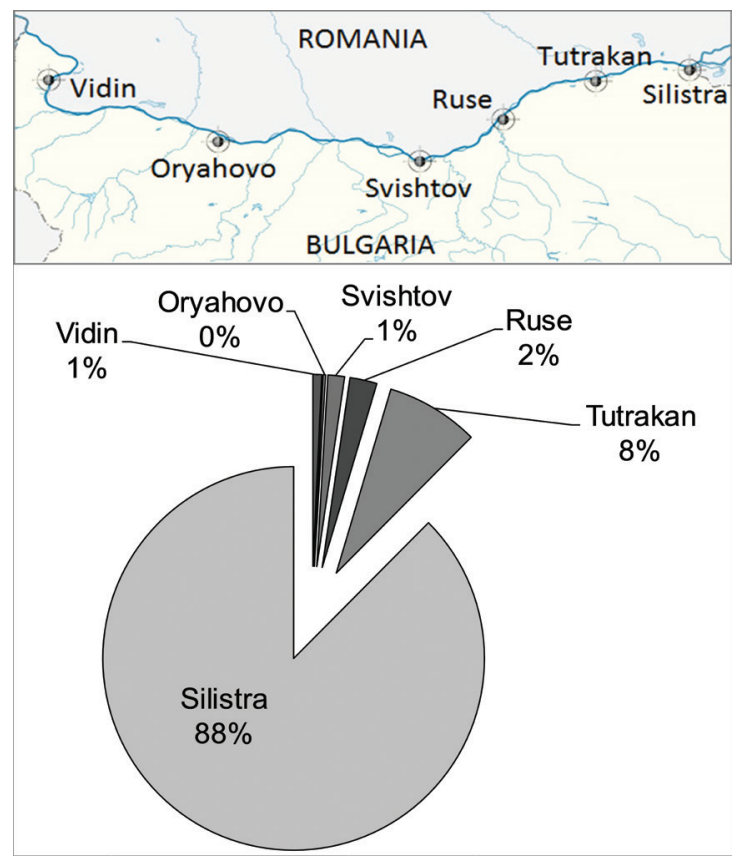

Figure 8. Map of Bulgarian section of Danube (above) and distribution of the catches by place of landing for 2006-2018 (below) (data source: The Executive Agency of Fisheries and Aquaculture (EAFA)). 
populations in the Danube and because of historical fluctuations in the commercial catch (Drensky 1951; Pomakov 1985; Trichkova and Stefanov 2011). The past and the present distribution of the species in Bulgaria is shown on Figure 1.

\section{Discussion}

The positive allometric growth $(\mathrm{b}>3)$ shown by our data means that the fish become less elongated or more roundish as they grow. In contrast, a negative allometric growth pattern was reported by Smederevac-Lalić et al. (2015) for the burbot population at Bachka Palanka (middle part of the Danube), although the fish had been caught in the same season. We assumed these differences in growth patterns may be attributed to different gonad development and food availability, as these are primary factors influencing body shape (Jennings et al. 2001). In our study, smaller fish had empty stomachs and larger ones exhibited in most cases developed gonads and prey in the stomach, which contributed to the positive allometric growth curve. We assume that the length growth of reproductive age females slows down faster as compared to the reproductive age males. However, this could not be proven statistically for the fish older than six years due to only few individuals at this age. This corresponds with the conclusion of Žiliukiene and Žiliukas (2010) that differences in growth rates of fish species are more pronounced in the older age groups.

The hardly visible first inner hyaline circle does not mark the end of the first biological year. It is formed during the comparatively short summer inactive period in the first year. This period is shorter in juvenile burbot than in older ones, as juveniles are more tolerant to higher temperatures (Nikcevic et al. 1995; Wolnicki et al. 2002), less stored glycogen and fat in the liver, and they stay active almost throughout the first year of their life in order to increase their size rapidly (Ryder and Pesendorfer 1992; McPhail and Paragamian 2000). Ryder and Pesendorfer (1992) found that larval growth is rapid in May and June but slows down in August, which represents only a short period of limited activity. The use of vertebrae for age determination in burbot proved to be very easy and reliable. As a disadvantage, it requires killing of the fish to obtain the aging structure. Specimens with extracted vertebrae also cannot easily be sold on the fish market, but this is also the case with the other commonly used methods based on otoliths (Guinn and Hallberg 1990; Pulliainen and Korhonen 1990).

The established sex ratio was similar as the reported by Pulliainen and Korhonen (1990) and Smederevac-Lalić et al. (2015). The domination of females in older ages may correspond to differences in the lifespan between sexes, but this remains speculative. Most authors agree that males mature about a year earlier than females (Janković 1986; Arndt and Hutchinson 2000; McPhail and Paragamian 2000), but this was not confirmed by our data. Probably some of the non-reproducing 5-year-old individuals were still immature but this is hardly relevant to the 6-year-old fish. Their sex was clearly evident, and we could not exclude the possibility if their maturity was delayed or if they were non-reproducing or even sterile. Many authors had reported high per- 
centage of non-reproducing fish for adult burbot (Hewson 1955; Evenson 1990; Pulliainen and Korhonen 1990, 1993). Segerstråle (1945) and Sandlund et al. (1985) suggested that burbot may have one or more rest years to restore their nutrition reserves after spawning. Baggerman (1980) and Stacey (1984) point out that exogenous factors, such as water temperature, salinity, photoperiod, and also social factors can delay sexual maturation. Instead, Pulliainen and Korhonen (1990, 1993) connected the large number of non-reproducing burbot with contaminants in the water, which cause sterility, than to presence of rest years.

The observed values of absolute fecundity were very similar to those reported by Brylińska et al. (2002) from Lake Hańcza, Poland. Similar size-egg number correlations can be found in other burbot populations, while the number of the eggs vary from 6300 (Miller 1970) to 3477699 (Roach and Evenson 1993).

Comparable growth and life expectancy (maximum -12 years) of burbot in Southeast Europe were reported by Simonović (2001), Višnjić́-Jeftić et al. (2014), and Smederevac-Lalić et al. (2015), but in cold water habitat such as the glacial lake Plav (Montenegro) it can reach a larger body size, up to $6 \mathrm{~kg}$ (Goran Tokić pers. comm.). According to McPhail and Paragamian (2000), the lifespan of the southern populations is shorter than in northern ones. Magnin and Fradette (1977) noted that individuals older than 7 years are rare in a population at $45^{\circ} \mathrm{N}$, but at $55^{\circ} \mathrm{N}$ most adults are 8 - to 12-years-old. The maximum ages recorded in northern populations were about 20-22 years (Guinn and Hallberg 1990). The growth rate of burbot in Romania, as reported by (Oţel 2007), is very similar to our results (Table 1 ).

Data clearly show that burbot is declining at least since the beginning of the century. Chronologically, the species was classified widespread and very numerous (Drensky 1951), Endangered (Pomakov 1985), occasional and threatened by extinction (Karapetkova and Zhivkov 2010), and Vulnerable (Trichkova and Stefanov 2011). In the past this species had been found in the Danube and in the lowland and upland sections of the Iskar and Yantra rivers, its largest tributaries (Kovachev 1923; Morov 1931; Shishkov 1939; Drensky 1951). At present, the species has lost most of its habitats in the tributary rivers, as they have been heavily affected by water pollution during $1960 \mathrm{~s}$ to 1980s (Rusev 1994), as well as by fragmentation, which is a strong negative impact on this migratory species (Fig. 9). Adult burbot tend to be middle-distance migrants (Waidbacher and Haidvogl 1998) and travel several to more than $250 \mathrm{~km}$ in one direction during seasonal migrations (Evenson 1993; McPhail and Paragamian 2000).

Nowadays, burbot inhabits primarily the Danube River and occasionally the Iskar (two adult specimens at Pisarovo village in 2009 during spring high waters; unpubl. data) and Yantra (one adult near the town of Byala in the summer of 2006 (Mihov and Koev 2006), and one adult at the same place in the summer of 2010 (unpubl. data)). The species has been recorded also in Skat River (Ogosta river basin), very close to its mouth near the Danube (Stefanov pers. comm.) (Fig. 1).

Stapanian et al. (2010) noted that the lack of trend data for many burbot populations has left them vulnerable to overfishing. Moreover, burbot is very susceptible to overfishing because much of the fishing effort typically targets aggregations during 


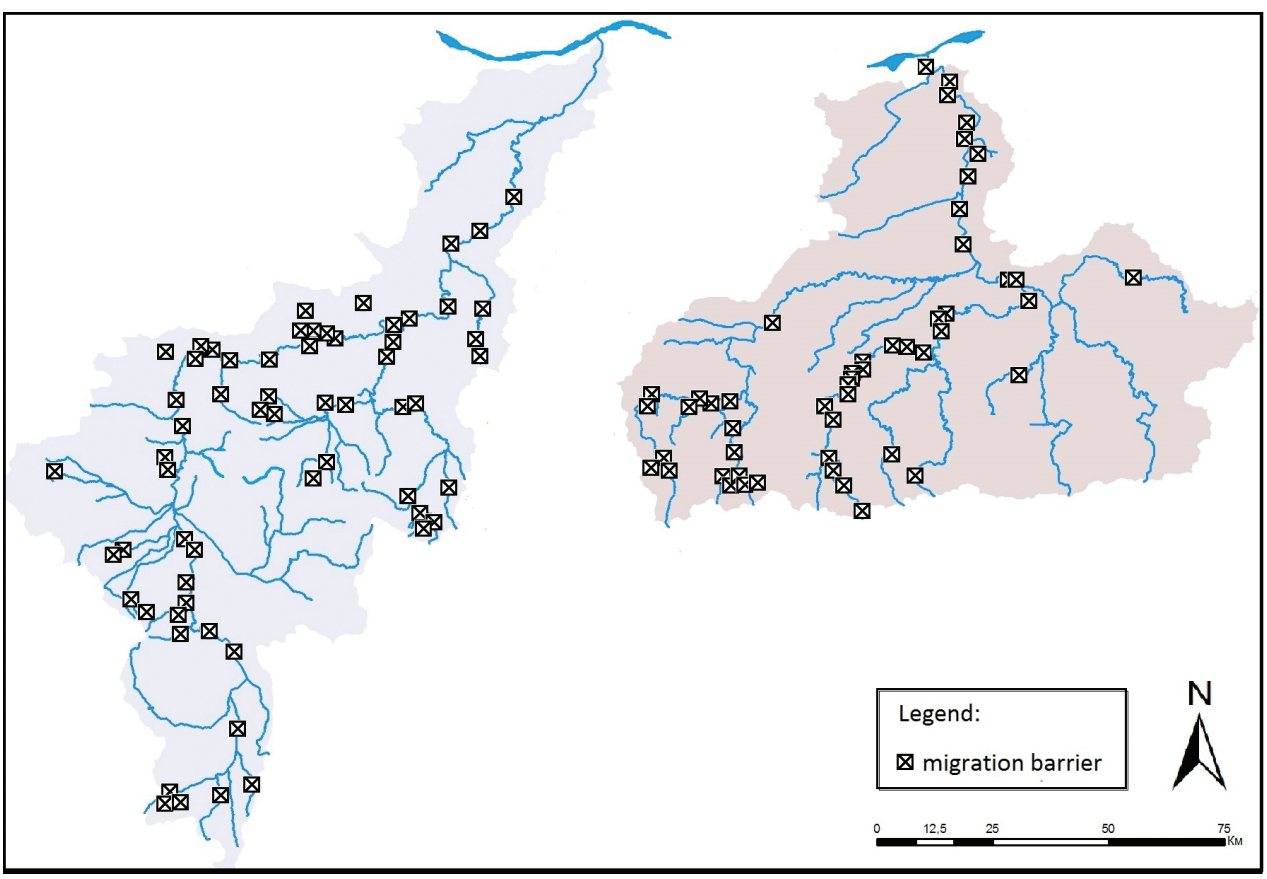

Figure 9. Migration barriers along Iskar (left) and Yantra (right) river catchments (data source: Basin Directorate Danube Pleven 2016).

spawning and feeding (Ahrens and Korman 2002). On the other hand, fishing efforts in Bulgaria are mainly concentrated in the eastern section of the Danube from Tutrakan to Silistra, which represents only part of the potential habitat of the species.

As the burbot's life cycle is cold-water dependent, Bulgarian populations live at the limit of the species' preferences, since these populations are at the southern edge of the burbot's range (Pomakov 1985). Therefore, the Bulgarian populations are especially vulnerable to habitat changes caused by climate change. For example, increases of water temperatures due to the climate change have been noted as a reason for declines in Lake Oneida (New York, USA) at the southern extent of the species' range (Jackson et al. 2008). According to the local Bulgarian fishermen, several years with abundant burbot are followed by a longer period of poor catches. Similar fluctuations were reported by (Švagždys 2002), who concluded that a warming climate has a strong negative impact on the reproduction of burbot in Curonian Lagoon and the lower Nemunas River (Lithuania). Svagzdys related the decrease in catches with winter floods and thaws, which cause high mortality of eggs during their incubation.

Basarin et al. (2016) reported a statistically significant long-term warming trend in water temperature (Tw) at three sites (Bezdan, Bogojevo, and Veliko Gradište) along the Serbian Danube, both for annual and seasonal minimums and maximums, by analyzing the mean monthly Tw records from 1950 to 2012. Basarin et al. (2016) detected a general increasing in Tw beginning in the 1980s, as shown by a time series of annual 


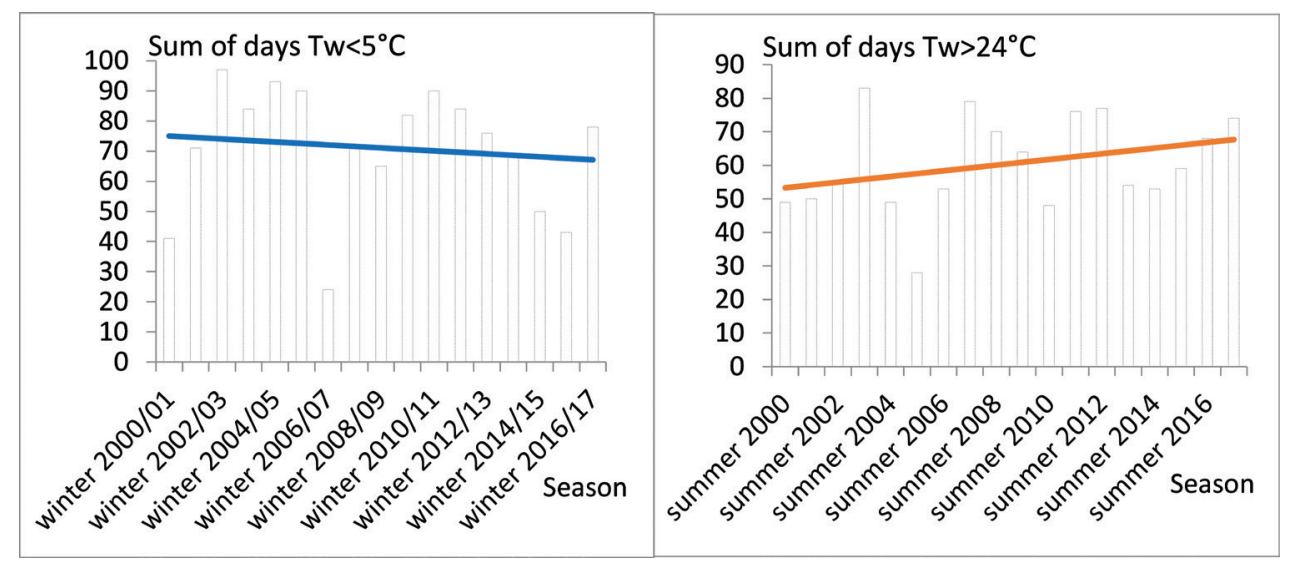

Figure 10. Sum of days with water temperature appropriate for reproduction and egg incubation $\left(\mathrm{Tw}<5^{\circ} \mathrm{C}\right.$, left $)$ and summer stress duration $\left(\mathrm{Tw}>24^{\circ} \mathrm{C}\right.$, right) per seasons (data source: Executive agency for exploration and maintenance of the Danube river (EAEMDR)).

mean values. A similar increase of the minimum and mean annual Tw of the Danube and its main tributaries in Croatia since 1988 was reported by Bonacci et al. (2008). A statistically significant increase $\left(0.039{ }^{\circ} \mathrm{C}\right.$ per year) in the mean annual Tw of the Danube at Bogojevo (Serbia) and increases in all the average monthly values between 1961 and 2013 were reported by Ducić et al. (2015). A comprehensive study on the trends in alterations of water temperatures across Elbe and Danube river basins warns that there is a significant risk for fundamental changes in river ecosystems, which may lead to significant distortions in community structure and composition Markovic et al. (2013). By analyzing long-term data sets, Markovic et al. (2013) found phase shifting in spring warming of almost two weeks, an increase in the number of the days with Tw above $25^{\circ} \mathrm{C}$, and an increase in the duration of summer heat stress. Although such studies are not available for the Lower Danube, data provided by EAEMDR from the hydrometric station at Silistra $(\mathrm{km} \mathrm{375.5),} \mathrm{confirms} \mathrm{the} \mathrm{amplification} \mathrm{of} \mathrm{the} \mathrm{summer}$ stress and shortening of the favorable reproduction period in the winter (Fig. 10). We calculated a decreasing trend in the number of the days with $\mathrm{Tw}$ below $5^{\circ} \mathrm{C}$ during the winter (Fig. 10, left), a strongly increasing trend of prolongation of the summer stress with $\mathrm{Tw}$ higher than $24^{\circ} \mathrm{C}$ (Fig. 10, right), and a trend of average increase of $\mathrm{Tw}$ with $0.056^{\circ} \mathrm{C}$ per year (Fig. 11) for 2000-2017. The continuously warming water temperatures is disastrous for the future of Bulgarian burbot populations considering that incubation of burbot eggs in temperature above $5{ }^{\circ} \mathrm{C}$ causes high mortality $(100 \%$ in the eyed-egg-stage) (Żarski et al. 2010) and summer stresses are prolonged.

Due to the observed dramatic decline over the last three generations and continuing negative influences, we recommend to increase the conservation status of this species in Bulgaria from Vunerable (Trichkova and Stefanov 2011) to Endangered (according to IUCN criteria CR A2cd, but down-listed to $\mathrm{EN}^{\circ}$ after correction for regional level of assessment). In neighboring Serbia and Romania, where Burbot is much more wide- 


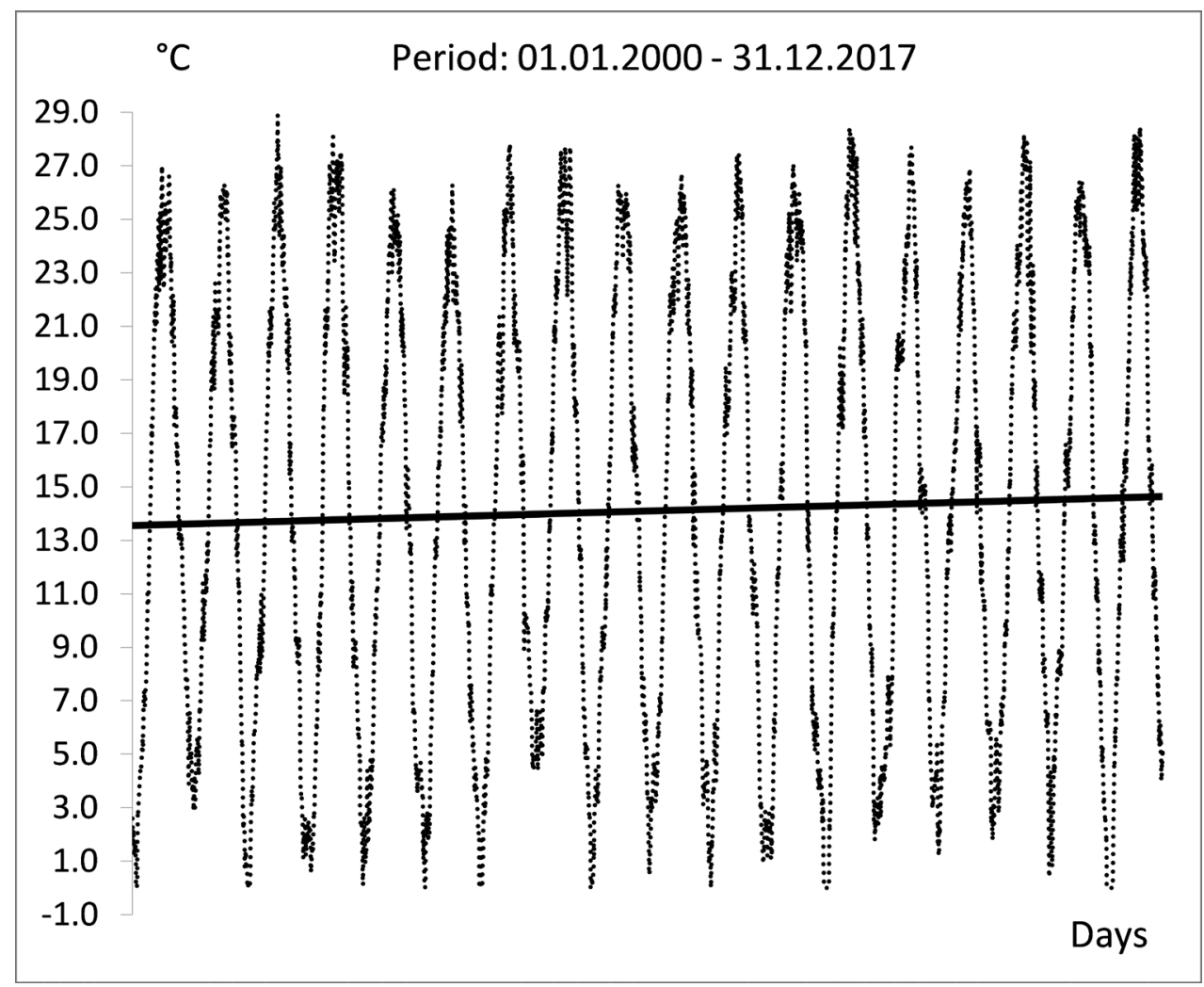

Figure I I. Daily water temperatures $\left({ }^{\circ} \mathrm{C}\right)$ in Danube at Silistra between 01.01.2000 and 31.12.2017 (data source: Executive agency for exploration and maintenance of the Danube river (EAEMDR)).

spread, it has the status of Least Concern and Vulnerable (Simonović 2001; Botnariuc and Tatole 2005; Oţel 2007). As a consequence of our research, we consider warming of water temperatures and fragmentation as the most important threats affecting the burbot in Bulgaria, and overfishing, pollution, and negative hydro-morphological changes as potential threats.

\section{Acknowledgements}

We are grateful to Lyubomira Lyubomirova and Anton Stamenov, who helped us in laboratory work and to Dr Tihomir Stefanov and Mr Goran Tokic for sharing with us their own data. We thank to the fishermen from Vetren and Silistra who helped us with the collection of the fish and provided comprehensive information. We express our gratefulness to the directors of Bulgarian EAFA and EAEMDR, Prof. Galin Nikolov and $\mathrm{Mr}$ Pavlin Tsonev, respectively, who kindly shared with us the official catch records and water temperature data sets. 


\section{References}

Ahrens R, Korman J (2002) What Happened to the West Arm Burbot Stock in Kootenay Lake? Use of an Age-Structured Population Model to Determine the Possible Causes of Recruitment Failure. Report prepared for the British Columbia Ministry of Water, Land, and Air Protection, Nelson (British Columbia), 30 pp. http://www.friendsofkootenaylake.ca/wpcontent/uploads/2016/03/Ahrens_Korman_2002_Burbot_Kootenay_Lake.pdf [Accessed on: 2019-6-20]

Arndt SKA, Hutchinson J (2000) Characteristics of Burbot spawning in a tributary of Columbia Lake, British Columbia, over a four-year period. In: Paragamian VL, Willis DW (Eds) Burbot: biology, ecology, and management. Fisheries Management Section of the American Fisheries Society, Nelson, Publication 1: 48-60.

Baggerman B (1980) Photoperiodic and Endogenous Control of the Annual Reproductive Cycle in Teleost Fishes. In: Ali MA (Ed.) Environmental Physiology of Fishes. NATO Advanced Study Institutes Series (Series A: Life Science), Vol. 35. Springer, Boston, 533-567. https://doi.org/10.1007/978-1-4899-3659-2_21

Basarin B, Lukić T, Pavić D, Wilby RL (2016) Trends and multi-annual variability of water temperatures in the River Danube, Serbia. Hydrological Processes 30(18): 3315-3329. https://doi.org/10.1002/hyp.10863

Basin Directorate Danube Pleven (2016) Review of significant antropogenic pressures and impacts on the status of surface- and ground-waters. In: River Basin Management Plan for the Danube Region 2016-2021. Ministry Council: No. 1110/29.12.2016, Sofia-Pleven, Bulgaria, 133 pp. [in Bulgarian] http://www.bd-dunav.org/uploads/content/files/upravlenie-na-vodite/PURB-2016-2021-final/Summary_RBMP_DR_29122016.pdf [Accessed on: 2018-12-9]

Berg LS (1949) Freshwater Fishes of the U.S.S.R. and Adjacent Countries. Vol. 3. Fourth Edition. Pavlovskiy EN (Ed.) Izdateljstvo Akademii nauk SSSR, Moscow, 927-1382 [in Russian].

Bertalanffy L (1951) Theoretische Biologie. Zweiter Band: Stoffwechsel, Wachstum. A. Francke, Bern, 418 pp.

Bonacci O, Trninić D, Roje-Bonacci T (2008) Analysis of the water temperature regime of the Danube and its tributaries in Croatia. Hydrological Processes 22(7): 1014-1021. https:// doi.org/10.1002/hyp.6975

Botnariuc N, Tatole V (2005) Cartea rosie a vertebratelor din Romania. Muzeul Naţional de Istorie Naturală "Grigore Antipa”, Bucharest, 260 pp.

Brylińska M, Chybowski L, Boguszewski A (2002) Reproductive Biology of Burbot, Lota lota lota, in Lake Hańcza, Poland. Folia Zoologica, Praha 51(2): 141-148.

Chapman DG (1961) Statistical problems in dynamics of exploited fisheries populations. Fourth Berkeley Symposium on Mathematics, Statistics and Probability, Volume 4: Contributions to Biology and Problems of Medicine, Berkeley, 1961. University of California Press, 153-168. https://projecteuclid.org/download/pdf_1/euclid.bsmsp/1200512883 [Accessed on: 2018-5-25] 
Drensky P (1951) Fishes in Bulgaria. Fauna of Bulgaria II. Bulgarian Academy of Sciences, Sofia, 270 pp. [in Bulgarian]

Ducić VD, Milenković MD, Milijašević DP, Vujačić DM, Bjeljac ŽN, Lović SI, Gajić MR, Andjelković GR, Djordjević AD (2015) Hiatus in global warming - example of water temperature of the Danube River at Bogojevo gauge (Serbia). Thermal Science 19(2): S467S476. https://doi.org/10.2298/TSCI150430133D

Edwards WH, Stapanian MA, Stoneman AT (2011) Precision of two methods for estimating age from burbot otoliths. Journal of Applied Ichthyology 27 (Supplement 1): 43-48. https://doi.org/10.1111/j.1439-0426.2011.01842.x

Evenson MJ (1990) Age and length at sexual maturity of burbot in the Tanana River, Alaska. Alaska Department of Fish and Game Division of Sport Fish Anchorage, Fishery Manuscript No. 90-2, Alaska, 10 pp. http://www.adfg.alaska.gov/FedAidpdfs/Fms90-02.pdf [Accessed on: 2018-7-15]

Evenson MJ (1993) Fishery Data Series Seasonal movements of radio-implanted burbot in the Tanana River drainage. Alaska Department of Fish and Game Division of Sport Fish Anchorage, Fishery Data Series No. 93-47, Alaska, 27 pp. http://www.adfg.alaska.gov/ FedAidpdfs/FDS93-47.pdf [Accessed on: 2018-7-15]

Froese R (2006) Cube law, condition factor and weight-length relationships: History, metaanalysis and recommendations. Journal of Applied Ichthyology 22: 241-253. https://doi. org/10.1111/j.1439-0426.2006.00805.x

Guinn DA, Hallberg JE (1990) Precision of estimated ages of burbot using vertebrae and otoliths. Fishery Data Series No. 90-17. Alaska Department of Fish and Game Division of Sport Fish, Anchorage, Juneau, Alaska, 17 pp.

Hardewig I, Pörtner HO, Van Dijk P (2004) How does the cold stenothermal gadoid Lota lota survive high water temperatures during summer? Journal of Comparative Physiology B 174: 149-156. https://doi.org/10.1007/s00360-003-0399-8

Hewson LC (1955) Age, maturity, spawning and food of Burbot, Lota lota, in Lake Winnipeg. Journal of the Fisheries Research Board of Canada 12(6): 930-940. https://doi. org/10.1139/f55-049

Holcík J (2003) Changes in the fish fauna and fisheries in the Slovak section of the Danube River: a review. International Journal of Limnology: Annales de Limnologie 39(3): 177195. https://doi.org/10.1051/limn/2003015

IUCN (2012a) Guidelines for Application of IUCN Red List Criteria at Regional and National Levels: Version 4.0. International Union for Conservation of Nature. Gland. Switzerland/ Cambridge, UK, iii + 41 pp. https://portals.iucn.org/library/sites/library/files/documents/ RL-2012-002.pdf [Accessed on: 2018-4-20]

IUCN (2012b) IUCN Red List Categories and Criteria: Version 3.1. Second Edition. International Union for Conservation of Nature. Gland, Switzerland/Cambridge, UK, iv + $32 \mathrm{pp}$. https://portals.iucn.org/library/sites/library/files/documents/RL-2001-001-2nd.pdf [Accessed on: 2018-4-20]

Jackson JR, VanDeValk AJ, Forney JL, Lantry BF, Brooking TE, Rudstam LG (2008) Longterm trends in burbot abundance in Oneida Lake, New York: life at the southern edge of the range in an era of climate change. In: Paragamian VL, Bennett DH (Eds) Burbot: 
Ecology, Management, and Culture. American Fisheries Society, Symposium 59, Bethesda, Maryland, $270 \mathrm{pp}$.

Janković D (1986) Taxonomical and ecological characteristics of burbot Lota lota (Linnaeus),

1758 from the Danube River (Yugoslavia). Ichthyologia (Yugoslavia) 18: 23-39.

Jennings S, Kaiser MJ, Reynolds JD (2001) Marine Fisheries Ecology. First Edition. Blackwell Science, Oxford, $432 \mathrm{pp}$.

Karapetkova M, Zhivkov M (2010) Fishes in Bulgaria. Second Edition. GEA-LIBRIS, Sofia, 216 pp. [in Bulgarian]

Kjellman J (2003) Growth and recruitment of burbot (Lota lota). Academic dissertation, University of Helsinki, Vaasa, Finland.

Kovachev V (1923) Freshwater Ichthyofauna of Bulgaria. Third Edition. Archives of the Ministry of Agriculture and State Property, Sofia, 164 pp. [in Bulgarian]

Kruk A (2007) Long-term changes in fish assemblages of the Widawka and Grabia rivers (Poland): pattern recognition with a Kohonen artificial neural network. Annales de Limnologie 43(4): 253-269. https://doi.org/10.1051/limn:2007004

Magnin E, Fradette C (1977) Growth and feeding habits of the burbot Lota lota (Linnaeus 1758) in various lakes and rivers of Quebec. Le Naturaliste Canadien 104(3): 207-222.

Markovic D, Scharfenberger U, Schmutz S, Pletterbauer F, Wolter C (2013) Variability and alterations of water temperatures across the Elbe and Danube river basins. Climatic Change 119: 375-389. https://doi.org/10.1007/s10584-013-0725-4

McPhail JD, Paragamian VL (2000) Burbot biology and life history. In: Paragamian VL, Willis DW (Eds) Burbot: Biology, Ecology, and Management. Fisheries Management Section of the American Fisheries Society 128 (Article 09): 11-23.

Mihov S, Koev V (2006) Study of the ichthyofauna and herpetofauna of the Yantra River and the Rusenski Lom River. BIOM Ltd., Belene, 75 pp. https://d2ouvy59p0dg6k.cloudfront. net/downloads/fauna_yantra_rusenski_lom_report2006.pdf [Accessed on: 2008-3-10. in Bulgarian]

Miller DD (1970) A Life History Study of Burbot in Boysen Reservoir, Ring Lake and Trail Lake: Part II Completion. Wyoming Game and Fish Commission, Dingell-Johnson Project, $115 \mathrm{pp}$.

Morov T (1931) The Freshwater Fishes of Bulgaria. Hudozhnik, Sofia, 93 pp. [in Bulgarian]

Nikcevic M, Hegedis A, Mickovic B, Bakovic A, Andjus RK (1995) The burbot (Lota lota L.) in Yugoslavia: habitats and thermal acclimation capacity. Ichthyologia (Yugoslavia) 27 (1): $5-11$.

Oţel V (2007) Atlasul pestilor din Rezervatia Biosferei Delta Dunarii. Centrul de Informare Tehnologică Delta Dunării, Tulcea, 482 pp. [in Romanian]

Pomakov V (1985) Burbot (Lota lota (Linnaeus, 1758)). In: Botev B, Peshev T (Eds) Red Data Book of Bulgaria. Vol. 2. Publishing House of Bulgarian Academy of Science, Sofia, 183 pp. [in Bulgarian]

Pulliainen E, Korhonen K (1990) Seasonal changes in condition indices in adult mature and non-maturing burbot, Lota lota (L.), in the north-eastern Bothnian Bay, northern Finland. Journal of Fish Biology 36: 251-259. https://doi.org/10.1111/j.1095-8649.1990. tb05600.x 
Pulliainen E, Korhonen K (1993) Does the burbot, Lota lota, have rest years between normal spawning seasons? Journal of Fish Biology 43: 355-362. https://doi. org/10.1111/j.1095-8649.1993.tb00570.x

Ricker WE (1975) Computation and Interpretation of Biological Statistics of Fish Populations.

Bulletin 191. In: Stevenson JC, Watson J, Wigmore RH, Reinhart JM (Eds) Environment

Canada and Fisheries and Marine Service, Bulletin 191: 1-382. https://www.dfo-mpo. gc.ca/Library/1485.pdf

Roach SM, Evenson MJ (1993) A Geometric Approach for Estimating and Predicting Fecundity of Tanana River Burbot. Alaska Department of Fish and Game Division of Sport Fish Anchorage, Fishery Data Series No. 93-98, Alaska, 36 pp. http://www.adfg.alaska.gov/ FedAidPDFs/fds93-38.pdf [Accessed on: 2018-6-10]

Rusev B (1994) Limnology of the Bulgarian Danube tributaries. Bulgarian Academy of Science: Institute of Zoology \& National Institute for Meteorology and Hydrology, Knizhen Tigar, Sofia, 256 pp. [in Bulgarian]

Ryder RA, Pesendorfer J (1992) Food, growth, habitat, and community interactions of zoungof-the-year burbot, Lota lota L., in a Precambrian Shield lake. Hydrobiologia 243/244: 211-227. https://doi.org/10.1007/BF00007037

Sandlund OT, Klyve L, Naesje TF (1985) Growth, habitat and food of burbot Lota lota in Lake Mjøsa. Fauna 38: 37-43.

Segerstråle C (1945) Leker laken (Lota vulgaris) i Finlands kustvatten med intervaller såsom laxfisk? Memoranda Societatis pro Fauna et Flora Fennica 21: 74-76.

Shishkov G (1939) Information on fishing on Iskar River. Ribarski Pregled 9(8): 4-7. [in Bulgarian] Simonović P (2001) Fishes of Serbia. In: Budakov L, Cvetković D, Petrov B, Šović V, Kovač V (Eds) NNK Internacional, Biološki Fakultet Univerziteta u Beogradu, Zavod za Zaštitu Prirode Srbije, Belgrade, 247 pp.

Skorić S, Smederevac-Lalić M, Višnjić-jeftić Ž, Hegediš A, Mićković B (2013) Relationships of otolith size to total length of the burbot (Lota lota) from the Danube River. VI International conference "Water \& Fish". Faculty of Agriculture, Belgrade-Zemun (Serbia), June 2013, 158-163.

Slavík O, Bartoš L (2002) Factors affecting migrations of burbot. Journal of Fish Biology 60: 989-998. https://doi.org/10.1006/jfbi.2002.1908

Smederevac-Lalić MM, Skorić SB, Višnjić-Jeftić ŽV, Djikanović VD, Mićković BM (2015) Growth and Weight-Length Relationship of Burbot Lota lota (L.) (Lotidae) in the Danube River at Bačka Palanka (Serbia). Acta Zoologica Bulgarica 67(1): 97-103. http://ibiss-r. rcub.bg.ac.rs/123456789/1992 [Accessed on: 2018-11-16]

Stacey NE (1984) Control of the timing of ovulation by exogenous and endogenous factors. In: Potts GW, Wootton RJ (Eds) Fish Reproduction: Strategies and Tactics. Academic Press, London, 207-222.

Stapanian MA, Paragamian VL, Madenjian CP, Jackson JR, Lappalainen J, Evenson MJ, Neufeld MD (2010) Worldwide status of burbot and conservation measures. Fish and Fisheries 11: 34-56. https://doi.org/10.1111/j.1467-2979.2009.00340.x

Švagždys A (2002) Growth and abundance of burbot in the Curonian Lagoon and determinatives of burbot abundance. Acta Zoologica Lituanica 12(1): 58-64. https://doi.org/10.10 80/13921657.2002.10512487 
Trichkova T, Stefanov T (2011) Burbot (Lota lota (Linnaeus, 1758)). In: Golemanski V (Ed.) Red Data Book of the Republic of Bulgaria. The Institute of Biodiversity and Ecosystem Research, Bulgarian Academy of Sciences \& Ministry of Environment and Waters, Sofia, 372 pp. http://e-ecodb.bas.bg/rdb/bg/vol2/Lolota.html [Accessed on: 2016-5-15 in Bulgarian] Tyulpanov MA (1967) Research on burbot biology in Ob river basin. Utch. zap. Tomskogo Universiteta 53: 133-152. [in Russian]

Višnjić-Jeftić Ž, Gačić Z, Skorić S, Smederevac-Lalić M, Đikanović V, Mićković B (2014) Population Structure of Burbot (Lota lota L.) in the Danube. Water Research and Management 4(2): 43-47. https://www.wrmjournal.com/images/stories/casopis/No_14/06.pdf [Accessed on: 2018-1-15]

Waidbacher HG, Haidvogl G (1998) Fish Migration and Fish Passage Facilities in the Danube: Past and Present: Fish Migration and Fish Bypasses. In: Jungwirth M, Schmutz S, Weiss S (Eds) Fish Migration and Fish Bypasses. Fishing News Books, Oxford, 85-98.

Wolnicki J, Kaminski R, Myszkowski L (2002) Temperature-influenced growth and survival of burbot Lota lota [L.] larvae fed live food under controlled conditions. Archives of Polish Fisheries 10(1): 109-113.

Żarski D, Kucharczyk D, Sasinowski W, Targońska K, Mamcarz A (2010) The influence of temperature on successful reproductions of burbot, Lota lota (L.) under hatchery conditions. Polish Journal of Natural Sciences 25(1): 93-105. https://doi.org/ 10.2478/v10020010-0007-9

Žiliukiene V, Žiliukas V (2010) Growth of pike Esox lucius L. in Lake Rubikiai (Lithuania). Journal of Applied Ichthyology 26(6): 898-903. https://doi.org/10.1111/j.14390426.2010.01517.x 